\title{
The Comparison of Verb Formation between English and Buton Tomiya Language
}

\author{
Windaryati ${ }^{1}$, Antonius M. K Naro ${ }^{2}$ \\ English Department \\ Faculty of Social Sciences Education and Humanities, \\ Muhammadiyah Maumere Teachers Training Institute \\ Maumere, NTT \\ wawanlabira@gmail.com
}

\begin{abstract}
The focus of this research is the comparison of verb formation between English and Buton Tomiya (BT) language, to know the similarities, differences. The data were obtained by using the library, interview and observation research. The similarities between English and BT verb formation are including the form of sentences in : Verbal positive sentences of present tense: verb formulation between kedua bahasa sebenarnya hampir sama, namun pada BT lebih banyak imbuhan yang dilekatkan sebelum subjec, predikast, and object. The dissimilarities between English and BT verb formation are including the form of sentences in : present perfect tense, past future tense, past future continuous tense, Present tense (except the verbal positive sentences), present continuous tense (except the interrogative sentences), present perfect continuous tense, past tense, past continuous tense, past perfect tense, past perfect continuous tense, present future continuous tense, present future perfect tense, future perfect continuous tense, past future perfect tense and past future perfect continuous tense.
\end{abstract}

\section{Keywords—contrative, verb formation, English language, Buton Tomiya Language.}

\section{INTRODUCTION}

The dialect uniqueness of the same language family has been contributing to the preservation of ethnic identity across the islands in Indonesia. In fact, there are many ethnic groups spread from Sabang to Marauke has different characteristics and characteristics from one language to another. The language and dialect are used to communicate among people within the ethnic group. In addition, they also have different cultural and social backgrounds with various types of shape. Therefore, various languages and cultures must be maintained to maintain diversity in unity as the legacy of the Indonesian state (Wacana, 2013).

Flores is one of the islands in South East Island Province which has many regions along with its countless regional language. The languages in Flores Island are languages belonging to the Austronesia language family. Blust (1977) also emphasized that the Polynesian Malay group which is a derivative of the Austronesian language consists of two groups, namely the West Polynesia Malay group and the Central/Eastern Polynesia Malay group. West Polynesia Malay Group down languages in the Philippines, Malaysia, Vietnam, Malagasy, western Indonesia (Sumatra, Java, Kalimantan, Sulawesi, Bali, Lombok, and western Sumbawa) while middle/eastern Indonesia decreases languages on the islands of Sumba, Flores, Timor, Central and southern Maluku.

Buton Tomiya language is a language is used by local people in Koja Doi Island, a small island to the north of Flores Island around 2 hours sailing by traditional boat. The whole population of the island is originally from tribe in southeast Sulawesi around a century ago along with their cultures and language.

The study of Buton language is very rare. It's proven with a little work on the Buton language in various ways. A study was done by Susiati and Rismaniye with title Languages of geographical languages and dialect in southeast Sulawesi (2018). The study aimed to figure out the differences and the similarities of in Southeast Sulawesi. Another study conducted by Hanan, (2010) divided the language in Sulawesi into seven groups, wrong the other is the Muna-Buton group whose members consist of MunaButon, South Buton, Wolio, Layolo, and Wakatobi. Wakatobi language as a language which are in the sub-cluster of Muna-Buton spoken on four islands, namely Wangi-Wangi, Kaledupa, Tomia, and Binongko islands. La Ino. (2014) classified the style in Southeast Sulawesi consists of two groups. The first group is Bungku-Tolaki which includes of the languages Wawonii, Kulisusu, Moronene, and Tolaki. The second group is Muna-Buton which consists of Busoa, Kambowa, Muna, Wolio, Cia-Cia, and Wakatobi. La Ino. (2016) stated that based on 
lexicostatistic calculation results of Muna-Wakatobi language relationship. The results of these calculations indicate that the two languages are in the sub-family category language or language differences with a reasonably close relationship between language relationships.

From those literatures reviewed, it is revealed that there has been no research on verb formation of Buton Tomia language. Yet, verb is so common in language use that they hardly need any introduction according to which they denote actions, activities, states, events, attitudes, processes, changes or existence enabling speakers to produce compressible utterances.

The starting point of studying verb formation may be the mapping of all verb types. Once we present all possible verb types, it may spare us a lot of subsequent explanations, and its real advantage lies in offering a logical view upon their possible combination to create tenses. Classifying verbs is important, as they express a multitude of grammatical categories, such as person (first, second, third) and number (singular, plural). Furthermore, in a syntactical approach, they express the predicate, offering the following possible characteristics: tense (present, past, future), aspect (simple, continuous or progressive, perfect (simple), perfect continuous or progressive), voice (active, passive), and mood (finite: indicative, imperative, subjunctive; non-finite: infinitive, gerund, participle).

In general linguistics, analysis of verb is concerned with the study of morphemes - the minimum meaning indivisible unit of a language. The task of computational morphology is to extract grammatical, syntactic, and semantic information from verb by using an expanded lexicon, which is treated as a separate part of a grammar. Isidore. (1975) stated that parsing of verb is a technique that aims to study the structure, type, morphophonemic, syntactic, and semantic properties of verb automatically. In Natural Language Processing it can be done at two levels.

Theodora. (1990) stated that traditional linguistic analysis of verbs is concerned with the study of their forms, and analysis of grammatical, morphemic, and semantic properties. Analysis of grammatical properties (e.g. markers of aspect, tense, auxiliary, person, number, particle, etc.) is necessary for understanding their forms and functions in the sentence. Here we deal with Buton Tomiya verb formation and compared it with English verb formation because understanding the structure of verbs can supply useful information to understand the structure of words of other parts-of-speech. Moreover, the understanding of the formation and function of verbs can give some clues to explore the nature of language cognition by the users.

\section{METHOD}

This study undertook the verb formation by making a comparison and contrast between English language and Buton language using contrastive analysis. It was concerned with the comparison and contrast of the two languages to determine their areas of similarities and differences with their implication on language learning and teaching (Darmawan \& Suryoputro, 2019). The method was proposed by Whitman (1970). There are four steps as components of contrastive analysis: (1) taking two languages, L1 and L2, and writing formal descriptions of them (or choosing descriptions of them), (2) picking forms from the descriptions for contrast, (3) making a contrast of the chosen form, and (5) making a prediction of the contrast.

This research took place at in Kojadoi Island, East Alok, Sub District of Sikka Regency Flores Island. The data were obtained from 20 adult native speakers of Buton Tomiya through interview and study literature.

\section{FINDING}

1. Buton Tomiya verb formation

a. Tomiya Buton Verbal Form Buton Tomiya verb forms are only known as Polymorphic because of verbal BT monomorphic, not including free morphemes. That form is a form that cannot stand alone except in the imperative mode (Verhaar: 2004). This pre-categorical form is called the main word (Ramlan: 2001).

b. Polymorphemic Verbs Formed through the Process of Affixation In BT the process of forming verbs with affixation consists of two forms, namely the affixing process of pronominal affixes and ordinary affixes. The process of affixing the pronominal affixes is obliged to be attached to the basic form except in the imperative mode which functions as the subject of the verb clause and Simultaneously functions as the filler of the predicate in the sentence.

c. Prefixs of Buton Tomia Verb Forming The verbforming prefixes in Buton Tomia consist of two forms, namely pronominal prefixes and ordinary prefixes, while pronominal prefixes are distinguished again from two forms namely realist and realistic forms.

d. Prefiks Buton Tomia :

1) Realist pronominal

Pro nominal realist referred to here is attached to the basic form which states that the perpetrators of the activities occurred, both past and ongoing by the basis (kridalaksana: 2001). the realist pronouns are $(\mathrm{Ku}),(\mathrm{u}),(\mathrm{no}),(\mathrm{ko}),($ to), (i).

The basic forms of verbs, nouns, adjectives adverbs and numerals can be attached directly to this prefix without going through the process of affixation with ordinary affixes. for example, we take the example of the basic form of the verb: 
- saii: create, can be placed with realist pronominal prefixes become: Kusaii, Usaii, Nosaii, Kosaii, Tosaii isaii.

- Guru : guru, from the basic form of nouns to being:Kugur, uguru, noguru, koguru, toguru, iguru.

-Da'o: bad, from the basic form of the adjectives to be: Kuda'o, Uda'o, Noda'o, Koda'o, Toda'o, Ida'o.

2) Realistic Pronominal Prefix

The iris pronominal prefix is a prefix attached to the basic form which states that the perpetrator carries out activities by the basis not or has not yet occurred (Karidalaksana: 2001). In the process of verb formation, infix insertion (um) in this basic form productively always follows verbs with realist prefixes. Which includes the original prefixing irons in BT are $(\mathrm{Ku})$; (ko), (a), (ka), (ta), (to).

3) Ordinary preffix

Ordinary prefixes are prefixes attached after the pronouns prefixes. These prefixes are: (pa), (po), (he), (to), (me), (ho), (pepe), (hopo), (hoko), (hoto), (para), (pisi), and (hiki). The usual prefixes above can be attached to the basic form of the verb: pamanga $=$ eat from the root word manga (eat), poga'a = divorced from the basic word ga'a (separate), hokomate $=$ abused from the word mate (died).

2. The similarities and the differences of English and Buton Tomia verb formation

1) The Similarities of Verb Formation between English and Buton Tomiya Language

Tabel 1.1 The Data Analysis of the Similarities between English and BT in verb formation

\begin{tabular}{|c|c|c|}
\hline Tense & English & Buton Tomia \\
\hline \multirow[b]{3}{*}{ 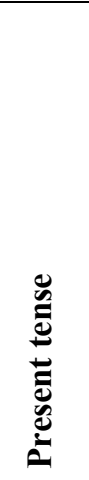 } & $(+)$ I go to market & (+) kulako ka daoa \\
\hline & $\begin{array}{l}\text { Pattern : } \\
S+V+\text { Adverb of } \\
\text { place }\end{array}$ & $\begin{array}{l}\text { Pattern: } \mathrm{S}+\mathrm{V}+ \\
\text { Adverb of place }\end{array}$ \\
\hline & \multicolumn{2}{|c|}{$\begin{array}{l}\text { We have a similarity in English and BT } \\
\text { present sentences. The similarity is in the } \\
\text { positive verbal sentences. But if the subjects } \\
\text { were the third singular person (he,she,it), } \\
\text { there will be a difference where English will } \\
\text { used the (V+s/es). This pattern are not found } \\
\text { in BT. }\end{array}$} \\
\hline
\end{tabular}

2). The differences of verb formation between Engish and Buton Tomia language Table 1.2 The Data Analysis of differences between English and Buton Tomia language in verb formation

\begin{tabular}{|c|c|c|}
\hline Tense & English & Buton Tomiya \\
\hline \multirow[t]{2}{*}{ 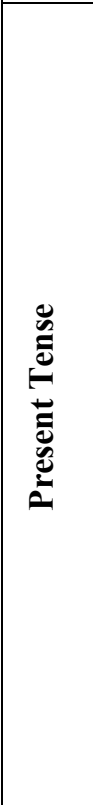 } & $\begin{array}{l}\text { (+) My father is a } \\
\text { Fisherman } \\
\text { Pattern : } \mathrm{S}+ \\
\text { auxiliary (to be) }+ \\
\text { C } \\
\text { (-) She doesneet } \\
\text { goes to school } \\
\text { Pattern : S + aux } \\
\text { (does)+Not }+\mathrm{V}+ \\
\text { Adverb of place. } \\
\text { (?)Why do you } \\
\text { hate me? } \\
\text { Pattern : Why }+ \text { aux } \\
\text { (do) }+\mathrm{S}+\mathrm{V}+\mathrm{O} ?\end{array}$ & $\begin{array}{l}\text { (+)Te amasu te patai- } \\
\text { tai } \\
\text { Pattern: } \\
\text { Prefiks te }+\mathrm{S}+\mathrm{P} \\
\text { (-) Di'iakai no lako } \\
\text { ka sekolah } \\
\text { Pattern: } \mathrm{S}+\mathrm{Ka} \text { 'i } \\
\text { +prefiks no }+\mathrm{P}+\mathrm{O} \\
\text { (?)Noahai'ko'omarik } \\
\text { aaku } \\
\text { Pattern : Noaha } \\
\text { +prefiks ' } \mathrm{i}+\mathrm{S}+\mathrm{P}+\mathrm{O}\end{array}$ \\
\hline & \multicolumn{2}{|c|}{$\begin{array}{l}\text { The form of present tense is almost same } \\
\text { with present sentences in BT The difference } \\
\text { just in present tense of English, they used } \\
\text { auxiliary but BT didn }{ }^{\text {eet }} \text { use it, they used } \\
\text { prefiks. }\end{array}$} \\
\hline \multirow{2}{*}{ 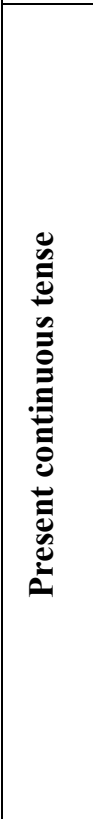 } & $\begin{array}{l}(+) \mathrm{Mr} \text {. Ary is } \\
\text { reading a book. } \\
\text { Pattern : } \mathrm{S}+\text { aux (to } \\
\text { be })+(\mathrm{V}+\text { ing })+\mathrm{O} / \mathrm{C} \\
(-) \text { They are not } \\
\text { cooking now } \\
\text { Pattern : } \mathrm{S}+\text { aux } \\
(\text { tobe })+\text { not }+ \\
(\mathrm{V}+\text { ing })+\text { Adverb of } \\
\text { time }\end{array}$ & $\begin{array}{l}(+) \text { La Ari no } \\
\text { bacateboku } \\
\text { Pattern : S+pref } \\
\text { No+ P + } \\
\text { prefiksTe+O } \\
(-) \text { 'Yammai ka'iho } \\
\text { no sai manga } \\
\text { Pattern :S + } \\
\text { Kai(not) + Suffix } \\
\text { Ho+ P }\end{array}$ \\
\hline & \multicolumn{2}{|c|}{$\begin{array}{l}\text { In present continuous tense and BT } \\
\text { continuous sentences, the form of sentences } \\
\text { were difference. English used V+ing but in } \\
\text { BT didn't using before the verb. The } \\
\text { differences were in English positive and } \\
\text { negative sentences, they used auxiliary and } \\
\text { BT didn't use it. }\end{array}$} \\
\hline
\end{tabular}




\begin{tabular}{|c|c|c|}
\hline \multirow[t]{2}{*}{ 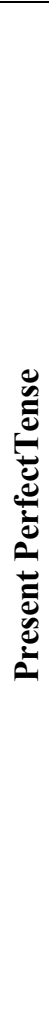 } & $\begin{array}{l}(+) \text { I have bought a } \\
\text { new shirt } \\
\text { Pattern : S + Have + } \\
\text { V3 + O } \\
(-) \text { I haven }{ }^{\text {eet }} \text { seen } \\
\text { you for a long time } \\
\text { Pattern : S + Haven }{ }^{e e} \mathrm{t} \\
+\mathrm{V} 3+\text { Adverb Of } \\
\text { Time } \\
(?) \text { Where have you } \\
\text { been? } \\
\text { Pattern : Where }+ \\
\text { Have }+\mathrm{S}+\text { aux } \\
\text { (been) }\end{array}$ & $\begin{array}{l}\text { (+)Di yaku } \\
\text { po'olimo balu te } \\
\text { kombo wo'ou } \\
\text { Pattern : prefiks Di } \\
+ \text { S + prefix } \\
\text { Po+Olimo + P + } \\
\text { prefiks +O } \\
\text { (-)Yaku meaho ku } \\
\text { simiinggko i'impi } \\
\text { alo mellengo } \\
\text { Pattern :S+ Meaho } \\
+ \text { suffix Ho } \\
+ \text { P+Adverb of time } \\
\text { (?) } \\
\text { Mina'ima'umpadoi } \\
\text { na 'Iko'o } \\
\text { Pattern : } \\
\text { mina'ima'umpa } \\
+ \text { prefiks } \\
\text { Na+prefiks I+S }\end{array}$ \\
\hline & \multicolumn{2}{|c|}{$\begin{array}{l}\text { In English present perfect tense, they used } \\
\text { the change of the verb form into V3, but in } \\
\text { BT used prefiks to change of verb form. } \\
\text { The form of sentence is almost same. }\end{array}$} \\
\hline \multirow[t]{2}{*}{ 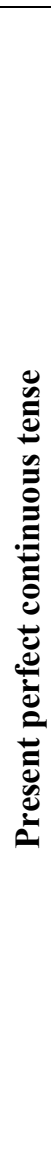 } & $\begin{array}{l}(+) \text { I have been } \\
\text { painting the door for } \\
\text { an hour. } \\
\text { Pattern : S + Have }+ \\
\text { aux (V+ing) + } \\
\text { O+adverb of time } \\
(-) \text { we have not been } \\
\text { studying English for } \\
\text { two month } \\
\text { Pattern : S + Have not } \\
+ \text { aux }+(\mathrm{V}+\text { ing })+\text { )/C } \\
(?) \\
(?) \text { Have dewi been } \\
\text { studying for an hour? } \\
\text { Pattern : Have }+\mathrm{S}+ \\
\text { aux }+(\mathrm{V}+\text { ing })+ \\
\text { adverb of time? }\end{array}$ & $\begin{array}{l}\text { (+)Yaku po'olimo } \\
\text { kamalo'e na } \\
\text { heloppo selama'a } \\
\text { Sajamu } \\
\text { Pattern : S + } \\
\text { po'olimo + P + } \\
\text { O+adverb of time } \\
\text { (-)Ikami meaho } \\
\text { belajar tanga } \\
\text { inggrisi Dua } \\
\text { kombammo } \\
\text { Pattern: } \\
\text { S+meaho+P+O+ad } \\
\text { verb of time } \\
\text { (?)Nopo'olimo ka'i } \\
\text { Wa Dewi belajar } \\
\text { sajamu? } \\
\text { Pattern : Preffix No } \\
+ \text { Po'olimo + } \\
\text { S+P+adverb of } \\
\text { time }\end{array}$ \\
\hline & \multicolumn{2}{|c|}{$\begin{array}{l}\text { In English present perfect continuous tense, } \\
\text { they used auxiliary before the verb, but BT } \\
\text { didn"t used it. English used (V+ing) that } \\
\text { usually means (sedang+V) in BT. But in } \\
\text { this case, Bahasa Indonesia didn"et use } \\
\text { "sedang" before the verb in sentences. }\end{array}$} \\
\hline
\end{tabular}

\begin{tabular}{|c|c|c|}
\hline & $\begin{array}{l}\text { (+) I went to the } \\
\text { garden yesterday } \\
\text { Pattern : } \mathrm{S}+\mathrm{V} 2+ \\
\text { Adverb of place } \\
\text { (-) They didn }{ }^{\text {eet go to }} \\
\text { school last week } \\
\text { Pattern : } \mathrm{S}+\text { aux } \\
\text { (did) }+ \text { not }+\mathrm{V}+ \\
\text { Adverb of pace }+ \\
\text { Adverb of time } \\
(?) \text { Did you come to } \\
\text { my house two hours } \\
\text { ago? } \\
\text { Pattern : Did }+\mathrm{S}+\mathrm{V} \\
+ \text { Adverb of pace }+ \\
\text { Adverb of time. }\end{array}$ & $\begin{array}{l}\text { (+)Inggawi ku lako } \\
\text { ka koboo } \\
\text { Pattern : } \\
\text { C+S+P+adverb of } \\
\text { place } \\
\text { (-)Yamma ika'i no } \\
\text { lako ka sikolaa'a } \\
\text { 'ahaji ihiyammo } \\
\text { Pattern : S+ka'i + } \\
\text { preffix No +P + } \\
\text { Adverb of place }+ \\
\text { Adverb of time } \\
(?) \text { Ummina ka'i } \\
\text { naIko'o 'ka sapo } 2 \\
\text { jamu ba'ai? } \\
\text { Pattern }: \text { Preffix Um } \\
+ \text { mina+Ka'i+preffI } \\
+ \text { S+adverb } \\
\text { ofplace+adverb of } \\
\text { time }\end{array}$ \\
\hline 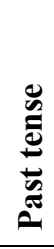 & \multicolumn{2}{|c|}{$\begin{array}{l}\text { In BT it always adds affixes to it.There are } \\
\text { no Just by adding the past adverb of time } \\
\text { such as "ba'ai" (Past) or "yang lalu" (ago), } \\
\text { in the sentences. English used the change of } \\
\text { verb form into V2 or the second form of } \\
\text { auxiliary in the sentences but BT didn"t. }\end{array}$} \\
\hline 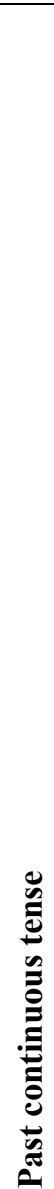 & $\begin{array}{l}\text { Pattern : } \mathrm{S}+\text { Aux }+ \\
\text { not }+(\mathrm{V}+\mathrm{ing})+ \\
\text { Adverb of time } \\
\text { (?) Were Irsan still } \\
\text { studying at nine } \\
\text { p.m. last night? } \\
\text { Pattern : Were }+\mathrm{S} \\
+(\mathrm{V}+\mathrm{ing})+\text { Adverb } \\
\text { of time? }\end{array}$ & $\begin{array}{l}\text { (+) Iyammai 'anne'e } \\
\text { no golu dimai'a wa } \\
\text { putri ka sapo su } \\
\text { Pattern :S+anne'e } \\
\text { +preff No+P+O+ } \\
\text { S+V+S+adverb of } \\
\text { place } \\
\text { (-) Te'inasu ka'iho no } \\
\text { saimanga pas } \\
\text { kuwaliako } \\
\text { (SEKOLAH???) } \\
\text { Pattern: Preff } \\
\text { Te+S+ka'i+suff ho+ } \\
\text { preff No+P+O/C } \\
\text { (?) 'I la irsan } \\
\text { anne'eho nobelajar } \\
\text { I'jam 9 } \\
\text { 'ikondoWIA? } \\
\text { Pattern : Preff I+S+ } \\
\text { anne'e+suffho+ preff } \\
\text { No+P +O/C }\end{array}$ \\
\hline
\end{tabular}




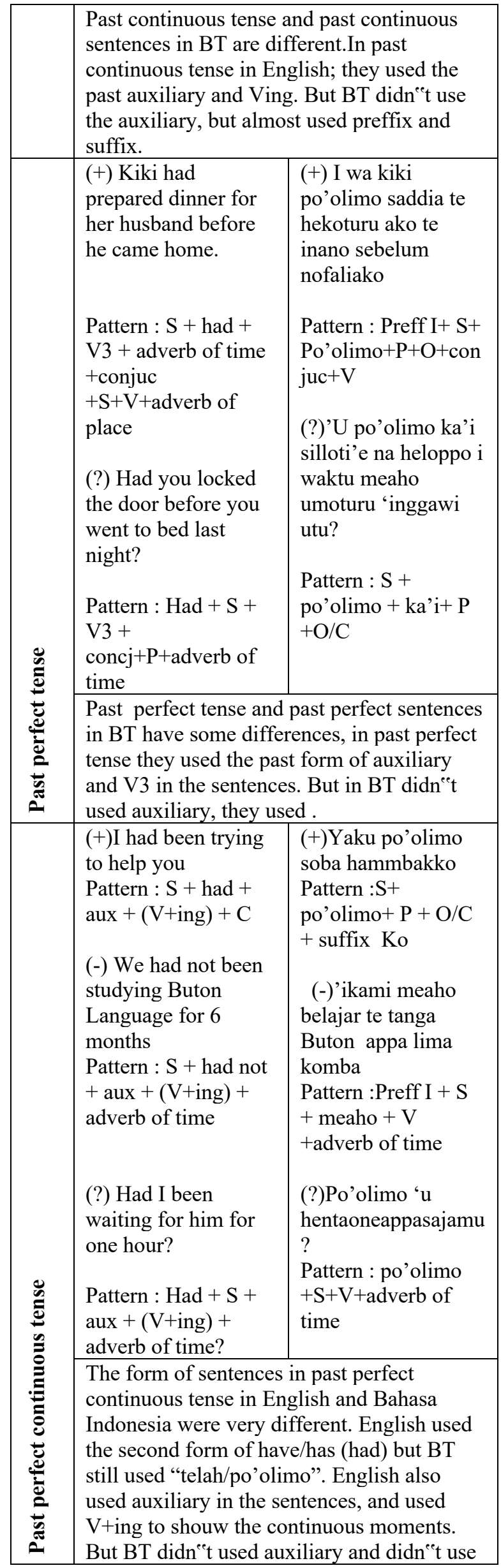

\begin{tabular}{|c|c|c|}
\hline & \multicolumn{2}{|c|}{$\begin{array}{l}\text { "po'olimo" to show the continouos } \\
\text { sentences. }\end{array}$} \\
\hline \multirow{2}{*}{ 造 } & $\begin{array}{l}\text { (+) I will be studying } \\
\text { for an exam. } \\
\text { Pattern : } \mathrm{S}+\text { will }+ \\
\text { aux }+(\mathrm{V}+\mathrm{ing})+\mathrm{C} \\
(-) \text { They wo eet be } \\
\text { playing football then } \\
\text { Pattern : } \mathrm{S}+\text { will not } \\
+ \text { aux }+(\mathrm{V}+\mathrm{ing})+\mathrm{C} \\
(?) \text { Will they be } \\
\text { singing tomorrow? } \\
\text { Pattern : Will }+\mathrm{S}+ \\
\text { aux }+(\mathrm{V}+\mathrm{ing})+ \\
\text { adverb of time? }\end{array}$ & $\begin{array}{l}\text { (+) Yaku 'a belajar } \\
\text { ako te ujian } \\
\text { Pattern : } \mathrm{S}+\text { 'a+V+C } \\
\text { (-)Iyammai ka'imo } \\
\text { a komulia golu } \\
\text { Pattern : } \\
\text { preffI+S+ka'imo+V } \\
+\mathrm{C} \\
(?) \text { Ammay 'a } \\
\text { mekadangki ka'i } \\
\text { 'ilange atu? } \\
\text { Pattern : } \\
\text { S+'a+V+adverb of } \\
\text { time }\end{array}$ \\
\hline & \multicolumn{2}{|c|}{$\begin{array}{l}\text { The difference in future continuous tense } \\
\text { and BT is the auxiliary. They used auxiliary } \\
\text { "be" in English, and used 'a auxiliary in BT. } \\
\text { In English they used (V+ing) as the } \\
\text { character of every continuous sentences. But } \\
\text { in BT furute continuous sentences, they } \\
\text { didn"t used "V-ing". Preffix 'a in BT have } \\
\text { the same meaning with will in Englis. }\end{array}$} \\
\hline \multirow{2}{*}{ 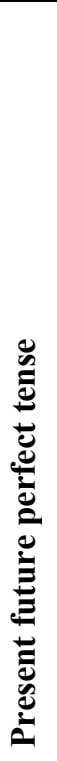 } & $\begin{array}{l}(+) \text { I will have } \\
\text { returned tomorrow } \\
\text { Pattern : S + will } \\
\text { have }+\mathrm{V} 3+\text { adverb } \\
\text { of time } \\
\text { (?) Will they have } \\
\text { arrived in Koja Doi } \\
\text { Island at } 9 \text { a.m? } \\
\text { Pattern : Will }+\mathrm{S}+ \\
\text { have }+\mathrm{V} 3+ \\
\text { Adverb of place }+ \\
\text { Adverb of time }\end{array}$ & $\begin{array}{l}\text { (+) Iyaku } \\
\text { kuhumaliako 'ilange } \\
\text { Pattern : preff I }+\mathrm{S}+ \\
\text { V+adverb of time } \\
(?) \text { 'ameaho 'a } \\
\text { ratomo na'ammai } \\
\text { 'ipulo 'ijamu } 9 \text { rea- } \\
\text { reaana? } \\
\text { Pattern : 'a }+\mathrm{P}+\text { preff } \\
\text { Na }+\mathrm{S}+\text { adverb of } \\
\text { place }+ \text { adverb of } \\
\text { time }\end{array}$ \\
\hline & \multicolumn{2}{|c|}{$\begin{array}{l}\text { The form of sentences in both language were } \\
\text { almost same, the difference of sentences } \\
\text { pattern in English and BT in the form of } \\
\text { verb in predicate. English used the V3 but } \\
\text { Bahasa Indonesia used preffix. }\end{array}$} \\
\hline
\end{tabular}




\begin{tabular}{|c|c|c|}
\hline 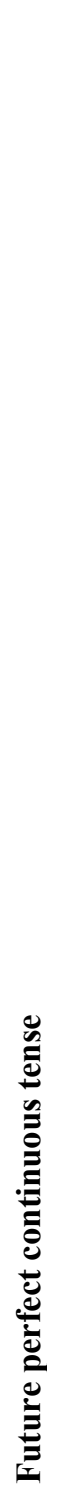 & 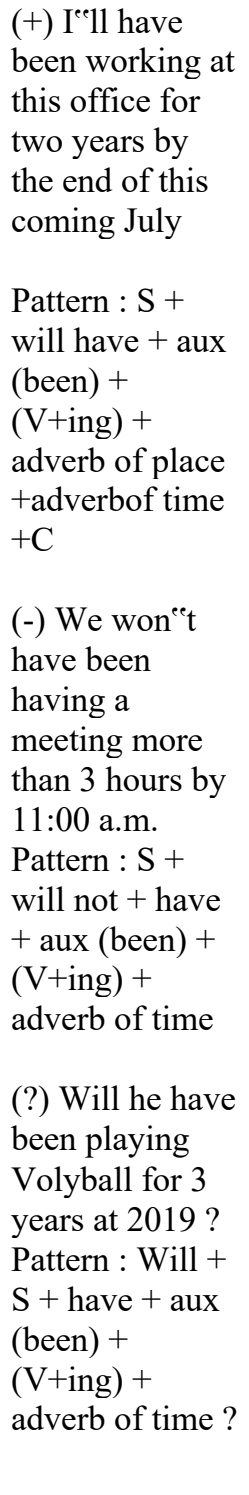 & $\begin{array}{l}\text { (+)Yaku ' po'olimokaraja } \\
\text { di kantoro mi'ana appa } \\
\text { dua ta'u dihia'ana di } \\
\text { akhiri july hadamai ana } \\
\text { Pattern : } \\
\text { S+po'olimo+V+adverb } \\
\text { of place +adverb of } \\
\text { time+C } \\
(-) \text { 'ikami mea 'a po'afa- } \\
\text { afa labi } 3 \text { jamu 'ijamu } 11 \\
\text { Pattern : pref 'I+S+mea } \\
\text { 'a+ V+adverb of time } \\
(?) \text { 'apo' olimoka'idi'iakol } \\
\text { ia voly appa } 3 \text { ta'u di ta'u } \\
\text { 2019? } \\
\text { Pattern : 'a+po'olimo+ } \\
\text { V+adverb of time }\end{array}$ \\
\hline & \multicolumn{2}{|c|}{$\begin{array}{l}\text { In future perfect continuous tense, they used } \\
\text { the auxiliary "been" in the sentences. And } \\
\text { thay also used "V+ing", BT didn"t use " 'a } \\
\text { and po'olimo" in the sentences. These things } \\
\text { that make differences between English and } \\
\text { BT future perfect continuous sentences. }\end{array}$} \\
\hline
\end{tabular}

\begin{tabular}{|c|c|c|c|}
\hline \multirow[b]{2}{*}{ 离 } & $\begin{array}{l}\text { (+) She would se } \\
\text { trousers from Ma } \\
\\
\text { Pattern : S + wou } \\
\mathrm{V}+\text { adverb of pl } \\
\\
\text { (-) She would not } \\
\text { the champion } \\
\text { Pattern : S + wou } \\
+\mathrm{P}+\mathrm{C} \\
\text { (?) Woud she } \\
\text { comeback tomorr } \\
\text { Pattern : Would }+ \\
\text { V + adverb of tim }\end{array}$ & $\begin{array}{l}\text { nd a } \\
\text { umere } \\
\text { Id }+ \\
\text { ace } \\
\text { be } \\
\text { Id not } \\
\\
\text { ow? } \\
\text { S + } \\
\text { e? }\end{array}$ & $\begin{array}{l}\text { (+)Di'ia 'a kahute } \\
\text { sala mina } \\
\text { Maumere } \\
\text { Pattern } \\
\text { :S+'a+P+te } \\
\text { (auxiliary } \\
\text { )+adverb of place } \\
\text { (-)di'ia mea 'a } \\
\text { kobe } \\
\text { Pattern : S+ } \\
\text { mea+'a + C } \\
\text { (?) di'ia 'a faliako } \\
\text { 'ilange? } \\
\text { Pattern : } \\
\text { S+'a+P+adverb } \\
\text { oftime }\end{array}$ \\
\hline & \multicolumn{3}{|c|}{$\begin{array}{l}\text { The form of sentences in past future tense } \\
\text { and past future sentences in BT is is } \\
\text { different. The differences are English is } \\
\text { using would (the past of will) in the } \\
\text { sentences. In BT is using 'a (akan) and } \\
\text { affixes. }\end{array}$} \\
\hline \multirow[t]{2}{*}{ 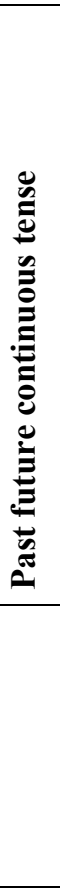 } & $\begin{array}{l}(+) \text { We would be } \\
\text { studying together } \\
\text { the exam } \\
\text { Pattern : S + wou } \\
\text { aux (be) }+(\mathrm{V}+\text { ins } \\
\mathrm{C} \\
\text { (?) Would they b } \\
\text { having a discuss } \\
\text { last night? }\end{array}$ & & $\begin{array}{l}\text { Kami 'a anne'e no } \\
\text { sisinga ako te ujian } \\
\text { Pattern : } \\
\text { S+'a+(anne'e)+V+C } \\
\text { (?)'a anne'e no } \\
\text { diskusi nggafi utu? } \\
\text { Pattern : } \\
\text { 'a+anne'e+prefNo+ } \\
\text { V+adverb of time }\end{array}$ \\
\hline & \multicolumn{3}{|c|}{$\begin{array}{l}\text { The differences between past future } \\
\text { continuous tense and BT sentences are } \\
\text { English used the second form of will } \\
\text { (would) and used auxiliary "be" in the } \\
\text { sentences. BT didn"t use it in the sentences, } \\
\text { they using 'a, preffiks No and anne'e } \\
\text { (serdang). }\end{array}$} \\
\hline 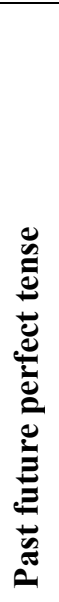 & $\begin{array}{l}\text { (+) Yuli should } \\
\text { have attended } \\
\text { the party if she } \\
\text { had got the } \\
\text { invitation } \\
\text { Pattern : S + } \\
\text { should + have + } \\
\text { V3 + C } \\
(-) \text { He wouldnot } \\
\text { have built the } \\
\text { house by } \\
\text { Oktober last } \\
\text { year. }\end{array}$ & $\begin{array}{l}(+) \mathrm{V} \\
\text { no ha } \\
\text { no af } \\
\text { Patte } \\
\text { S+sa } \\
+\mathrm{V}+\mathrm{C} \\
(-) \mathrm{D} \\
\text { anne } \\
\text { komb } \\
\text { Patte } \\
\text { S+ka } \\
+\mathrm{V}+\end{array}$ & $\begin{array}{l}\text { Va Yuli sammpuuno } \\
\text { adiri tepesta aradia'ia } \\
\text { ate undangan } \\
\text { rn : } \\
\text { mppuuno+preff No } \\
\text { C } \\
\text { i'iaka'i 'a } \\
\text { 'ehetadetesapo di } \\
\text { paaompuluta'ulalu. } \\
\text { rn : } \\
\text { i(auxiliary)+anne'e } \\
\text { O + Adverb of time }\end{array}$ \\
\hline
\end{tabular}




\begin{tabular}{|l|l|}
\hline & $\begin{array}{l}\text { Pattern }: \mathrm{S}+ \\
\text { wouldn } \mathrm{t}+ \\
\text { have }+\mathrm{V} 3+\mathrm{O} \\
+ \text { Adverb of } \\
\text { time }\end{array}$ \\
\hline & $\begin{array}{l}\text { In past future perfect tense, Engish used the } \\
\text { second form of shall/will (should/would) } \\
\text { and the V3 in forming the sentences. But } \\
\text { the form of sentences were same with BT. }\end{array}$ \\
\hline
\end{tabular}

The similarities and the dissimilarities

The finding in this research is found that between English and Buton Tomiya Verb formation pattern there are some similarities and dissimilarities in terms of forms and functions. As the following :

1. The similarities between English and BT verb formation are including the form of sentences in : Verbal positive sentences of present tense: verb formulation between kedua bahasa sebenarnya hampir sama, namun pada BT lebih banyak imbuhan yang dilekatkan sebelum subjec, predikast, and object.

2. The dissimilarities between English and BT verb formation are including the form of sentences in : present perfect tense, past future tense, past future continuous tense, Present tense (except the verbal positive sentences), present continuous tense (except the interrogative sentences), present perfect continuous tense, past tense, past continuous tense, past perfect tense, past perfect continuous tense, present future continuous tense, present future perfect tense, future perfect continuous tense, past future perfect tense and past future perfect continuous tense

\section{CONCLUSIONS AND SUGGESTIONS}

a. Conclusions

After analyzing the data in BT verb formation in term of form and function, conclusions can be drawn as following : Between English and BT verb formation in term pattern have similarities, some tenses in English are having same form of sentences. Both of English and Buton Tomiya (BT) in verbal positive sentences of present tense used $\mathrm{V}+\mathrm{S}+\mathrm{O} / \mathrm{C}$. Sentences of future tense in Engish and BT used $\mathrm{S}$ + will $+\mathrm{P}(\mathrm{V})+\mathrm{O} / \mathrm{C}$ in positive sentences, $\mathrm{S}+\mathrm{Will}$ not $+\mathrm{P}(\mathrm{V})+\mathrm{O} / \mathrm{C}$ in negative sentences, will $+\mathrm{S}+$ $\mathrm{P}(\mathrm{V})+\mathrm{O} / \mathrm{C}$ ? in interrogative sentences, in Bahasa Indonesia "will" means “ 'a ". Interrogative sentences of present continuous tense also have the same of Verb form in both languages. The dissimilarities between English and BT general sentences pattern are including the form of sentences in : Present tense (except the verbal positive sentences), present continuous tense (except the interrogative sentences), present perfect tense, present perfect continuous tense, past tense, past continuous tense, past perfect tense, past perfect continuous tense, present future continuous tense, present future perfect tense, future perfect continuous tense, past future tense, past future continuous tense, past future perfect tense and past future perfect continuous tense.

The dissimilarities in both languages commonly caused by the verb form that changed in English caused by Auxiliary,time and BT change of verb form with affixes. Example : In past tense, the from of sentences was $\mathrm{S}+\mathrm{V} 2+\mathrm{O} / \mathrm{C}$, such as "I went to the school last week", but BT only used $\mathrm{S}+\mathrm{V}+\mathrm{O} / \mathrm{C}$ (the past adverb of time), such as "yaku lako ka sekolah "inggawi". The use of auxiliary also always caused dissimilarities of verb form in both languages, because BT areusing affixesand never used auxiliary in the sentences. Example : In present tense nominal positive sentences used $\mathrm{S}+$ auxiliary $+\mathrm{P}$, such as "My Father is a Fisherman", but in BT only used S $+\mathrm{P}$, that was "Te amasu te patai-tai".

b. Suggestions

In relation to the conclusions, suggestion are staged as follow :

c. The researcher suggest that as people from Buton Tomiya, we must know about the verb formulation of Buton Tomiya Language, the differences between the form of sentence in our own language and the international language.

$d$. The researcher hopes that the thesis could be one of the related references for those who have interested in English and BT. It is xpcted that they can deepen their knowledge in both languages.

\section{REFERENCES}

[1] Abbas, H. (1981). Struktur Bahasa Wolio. Jakarta: Pusat Pembinaan dan Pengembangan Bahasa.

[2] Bynon, Theodora. (1990). Historical Linguistics. London: Cambridge University Press.

[3] Darmawan \& Suryoputro, 2019, The Comparison of the Phonological Features of Sikka Language and English, Vol. 4, No. 1, 2019, 64-72 DOI: 10.22236/JER_Vol4Issue1.

[4] Whitman, R. L. (1970). Contrastive analysis: Problems and procedures. Language Learning, 20(2), 191-197.

[5] La Ino. (2016). "The Reconstruction of Protolanguage Muna and Kambowa" in International Journal of Linguistics Literature and Culture (IJLLC), Vol. 2 No. 3 September 2016 ISSN: $2455-8028$ page $125-140$.

[6] La Ino. (2014). "Kekerbatan BahasaMuna, Wolio, dan Tolaki dalam Angka: Suatu Analisis Leksikostatistik" dalam Jurna 1Langua Vol. 4 No. 1 April 2014. Lembaga Kajian Ekolinguistik; Medan. 
[7] Dyen, Isidore. (1975). Linguistic Subgrouping and Lexicostatistic. The Hague Paris: Mouton.

[8] Ramlan. (1987). Sintaksis Ilmu Bahasa Indonesia. Yogyakarta: Karyono. 